\title{
Perbandingan Efek Induksi Propofol dengan Ketamin terhadap Penurunan Nilai Neutrofil pada Pasien dengan Tindakan Anestesi Umum
}

\author{
Angga Permana Putra, Hasanul Arifin, Chairul M. Mursin \\ SMF Anestesiologi dan Terapi Intensif Fakultas Kedokteran Universitas Sumatera Utara/ \\ Rumah Sakit Umum Pusat H. Adam Malik Medan
}

\begin{abstract}
Abstrak
Leukositmerupakan bagian dari imunitas bawaan. Penurunan nilai neutrofil dapat dipakai sebagai parameter yang sederhana untuk mengukur berat ringannya stres dan inflamasi sistemik pada pasien. Beberapa penelitian mengemukakan pengaruh obat-obat anestesi terhadap leukosit dan penelitian yang lain melihat dari pengaruh obat-obat anestesi terhadap fungsi dari subset leukosit terutama neutrofil. Tujuan penelitian ini mengetahui perbedaan efek induksi propofol dengan ketamin terhadap penurunan nilai neutrofil pada pasien dengan tindakan anestesi umum di Instalasi Bedah Pusat Rumah Sakit Umum Pusat H. Adam Malik Medan mulai Mei-Juni 2016. Penelitian uji klinis dengan randomized control trial double blind dilakukan pada 32 pasien ASA I dan II dibagi dalam 2 kelompok yang menjalani operasi dengan anestesi umum. Pasien pada kelompok propofol (A) diberikan induksi dengan propofol $2 \mathrm{mg} / \mathrm{kgBB}$. Kelompok ketamin diinduksi ketamin $2 \mathrm{mg} / \mathrm{kgBB}$. Kemudian diukur nilai neutrofil (\%) pada saat sebelum induksi (T1), 10 menit setelah intubasi (T2), dan 60 menit setelah insisi kulit (T3). Dengan SPSS ver.23, Uji T-independen dan Mann-Whitney U didapatkan hasil T1 neutrofil nilai $p=0,636$, T2 neutrofil nilai $p=0,846$, T3 neutrofil nilai $p=0,403$. Simpulan, terdapat perbedaan efek induksi antara propofol dan ketamin terhadap penurunan nilai neutrofil. Terdapat pengaruh ketamin terhadap penurunan nilai neutrofil, tetapi tidak ada pengaruh propofol terhadap penurunan nilai neutrofil.
\end{abstract}

Kata kunci: Ketamin, leukosit, neutrofil, propofol

\section{Comparison of Induction Effect between Propofol and Ketamine against Impairment of Neutrophils in Patient with General Anesthesia}

\begin{abstract}
Leukocyte is a part of innate immunity elements. Neutrophil impairment of can be used as a simple parameter to measure the severity of stress and systemic inflammation in patients. Some research suggests the influence of anesthetic drugs on leukocytes and other studies look at the effect of anesthetic drugs on leukocyte subset functions, especially neutrophils. This study aimed to reveal the difference in the induction effect of propofol and ketamine against impairment of neutrophils in patients with general anesthesia. This was a double blind randomized control trial conducted in 32 patients ASA I and II who were divided into two groups. These patients underwent general anesthesia at the Central Operating Theater of H. Adam Malik General Hospital during May-June 2016. Group propofol (A) received $2 \mathrm{mg} / \mathrm{kgBW}$ propofol, while group ketamine (B) received $2 \mathrm{mg} / \mathrm{kgBW}$ ketamine. Neutrophils were measured before induction (T1), 10 minutes after intubation (T2), and 60 minutes after intubation (T3). By using T-independent and MannWhitney U test in SPSS ver.23, it was found that the the p-values for T1. T2, and T3 neutrophils were 0.636 , 0.846 , and 0.403 . respectively. In conclusion, there is a difference in induction effect between propofol and ketamine against impairment of neutrophils with no effect is found for propofol.
\end{abstract}

Key words: Ketamine, leukocyte, neutrophils, propofol

Korespondensi: Angga Permana Putra, dr., SpAn, SMF Anestesiologi dan Terapi Intensif Fakultas Kedokteran Universitas Sumatera Utara/Rumah Sakit Umum Pusat H. Adam Malik Medan, Jl. Bunga Lau No. 17 Medan, Tlpn. 061-8362080, Mobile 082160405123,Email dr. angga.permana.putra@gmail.com 


\section{Pendahuluan}

Inflamasi adalah respons jaringan terhadap berbagai macam trauma. Hal ini merupakan bagian terpenting dari imunitas innate, juga merupakan inisiator dan juga regulator yang penting pada respons imun adaptif. Inflamasi melibatkan mikrovaskularisasi jaringan yang terkena, terutama venula post capiler. Sistem imun pasien yang menjalani pembedahan dipengaruhi oleh tindakan anestesi maupun tindakan pembedahan itu sendiri. ${ }^{1}$

Aksis hipotalamus-hipofisis-adrenal dan sistem saraf simpatis akan aktif seiring stres pembedahan, transfusi darah, hipotermia, hiperglikemia, dan nyeri. Tindakan anestesi menyebabkan penekanan langsung aktifitas sistem imunitas seluler dan neuro-hormonal sehingga berpengaruh terhadap fungsi sel imunokompeten serta ekspresi dan sekresi mediator inflamasi. Imunosupresi oleh anestesi khususnya terjadi pada penderita kanker, seperti disfungsi natural killer (NK) dan limfosit yang mempercepat pertumbuhan dan metastasis sel-sel ganas sehingga akan memperburuk prognosis. ${ }^{2}$

Leukosit merupakan bagian dari imunitas innate (bawaan). Komponen selular imunitas innate terdiri atas beberapa tipe sel dan banyak ditemukan pada tempat masuknya patogen. Contoh sel tersebut adalah sel natural killer (NK), sel polimorfonuklear (PMN), makrofag, dan sel dendrit. ${ }^{3}$

Neutrofil/limfosit rasio (NLR) merupakan marker sederhana respons inflamasi. Nilai NLR darah perifer digunakan sebagai parameter yang memberikan informasi hubungan antara lingkungan inflamasi dan fisiologi stres. Hasil penelitian yang telah dilakukan menunjukkan perbedaan yang signifikan nilai NLR selama periode pascaoperasi. Nilai pascaoperatif NLR pada pasien SC yang menjalani anestesi spinal lebih rendah dibanding dengan pasien yang menjalani anestesi umum. ${ }^{4}$

Penelitian yang membandingkan respons leukosit pada pasien pembedahan abdomen dengan teknik anastesi epidural dan teknik anastesi umum telah dilakukan oleh Kim dkk. ${ }^{5}$ Pada kelompok dengan teknik anestesi umum tampak angka hitung neutrofil yang menurun, namun jumlah leukosit meningkat dibanding dengan kelompok anastesi epidural. Penelitian ini menggambarkan bahwa neutrofil menurun disebabkan penggunaan netrofil pada lokasi insisi, namun angka leukosit yang meningkat merupakan akibat stimulasi sistem imun yang menunjukkan respons stres. ${ }^{5}$

Beberapa hasil penelitian mengemukakan pengaruh anestesi terhadap leukosit dan fungsi subset leukosit. Penelitian yang dilakukan oleh Kim dkk. ${ }^{5}$ melihat perbedaan respons leukosit terhadap insisi selama bedah upper abdomen antara epidural dan general anestesi. Sementara Roesslein dkk. ${ }^{6}$ menemukan efek tiopental untuk menjaga limfosit $\mathrm{T}$ manusia dari apoptosis.

Penelitian ini dilakukan berdasarkan pada besarnya pengaruh leukosit terhadap status imun pasien yang menjalani pembedahan dan dari beberapa penelitian menyatakan terdapat pengaruh agen anestesi terhadap perubahan neutrofil dan status imunitas pasien. Penelitian ini bertujuan membandingkan efek induksi propofol dengan ketamin terhadap penurunan nilai neutrofil pada pasien dengan tindakan anestesi umum.

\section{Subjek dan Metode}

Penelitian ini merupakan penelitian uji klinis dengan randomized control trial double blind membandingkan efek induksi propofol dengan ketamin terhadap penurunan nilai neutrofil pada pasien dengan tindakan anestesi umum. Populasi yang diikutsertakan dalam penelitian ini adalah pasien yang menjalani pembedahan elektif memakai anestesi umum di Instalasi Bedah Pusat Rumah Sakit Umum Pusat H. Adam Malik Medan mulai Mei sampai dengan Juni 2016. Seluruh populasi yang memenuhi kriteria inklusi dan tidak termasuk kriteria eksklusi dijadikan subjek penelitian. Kriteria inklusi penelitian ini adalah jenis kelamin lakilaki dan perempuan yang berusia 17-65 tahun, status fisik ASA I dan II, serta hasil pemeriksaan darah rutin dalam batas normal. Kriteria eksklusi penelitian ini adalah pasien dengan penyakit infeksi atau sepsis, pasien dengan 
riwayat hipertensi, mendapatkan transfusi darah sebelum induksi anestesi, serta pasien mempunyai riwayat alergi terhadap propofol dan ketamin. Untuk menentukan besar sampel menggunakan rumus uji hipotesis dua arah terhadap rata-rata dua populasi pada dua kelompok independen dan didapatkan besar sampel adalah 32 orang.

Setelah mendapatkan persetujuan etik dari Komite Etik RSUP HAM/FK USU, maka pasien ASA I dan II yang tiba di kamar operasi yang dijadwalkan untuk dilakukan operasi dengan anestesi umum dilakukan identifikasi identitas dan monitoring standar, kemudian dilakukan randomisasi untuk mengalokasikan subjek penelitian ke dalam kelompok A (propofol) atau kelompok B (ketamin), diambil sampel ke-1 (T1) darah vena sebanyak 2,5-3 mL. Dilakukan premedikasi dengan 0,05 mg/kgBB (i.v.) dan fentanil $2 \mu \mathrm{g} / \mathrm{kgBB}$ (i.v.) pada kedua kelompok, kemudian kelompok A diberikan induksi propofol $2 \mathrm{mg} / \mathrm{kgBB}$ (i.v.), untuk kelompok B diberikan induksi ketamin $2 \mathrm{mg} /$ kgBB (i.v.), dilanjutkan pemberian rokuronium
$1 \mathrm{mg} / \mathrm{kgBB}$ pada kedua kelompok, intubasi endotrakeal dan inhalasi sevofluran 1-2 vol\%. Sepuluh menit setelah intubasi diambil sampel ke-2 (T2) sebanyak 2,5-3 mL, 60 menit setelah insisi diambil sampel ke-3 (T3) sebanyak 2,5$3 \mathrm{~mL}$. Ketiga sampel darah kemudian dibawa ke laboratorium Patologi Klinik Rumah Sakit Umum Pusat H. Adam Malik Medan untuk diolah. Hasil penilaian dilakukan analisis statistika dengan memakai perangkat lunak Statistical Product and Service Solution (SPSS) ver. 23 untuk.

\section{Hasil}

Penelitian ini diikuti oleh 32 subjek penelitian yang telah memenuhi kriteria inklusi. Tidak didapatkan perbedaan karakteristik demografi yang signifikan menurut jenis kelamin, usia, berat badan, dan status fisik ASA antara kedua kelompok ( $p>0,05$; Tabel 1).

Nilai neutrofil dan leukosit rata-rata pada kelompok A antara sebelum induksi, 10 menit setelah induksi, dan 60 menit setelah insisi

Tabel 1 Karakteristik Demografi Subjek Penelitian

\begin{tabular}{llll}
\hline \multicolumn{1}{c}{ Karakteristik Demografi } & \multicolumn{1}{c}{$\begin{array}{c}\text { Kelompok A } \\
(\mathbf{n = 1 6 )}\end{array}$} & $\begin{array}{c}\text { Kelompok B } \\
(\mathbf{n = 1 6 )}\end{array}$ & Nilai p \\
\hline Jenis kelamin, n & & 7 & \\
$\quad$ Laki-laki & 8 & 9 & $\left.0,723^{*}\right)$ \\
$\quad$ Perempuan & 8 & $39,88(14,64)$ & $\left.0,476^{* *}\right)$ \\
Usia, rata-rata (SB), tahun & $36(15,72)$ & $56,25(6,19)$ & $\left.1,000^{* * *}\right)$ \\
Berat badan, rata-rata (SB), kg & $57,5(9,31)$ & & \\
Divisi, n & & 2 & $\left.0,229^{*}\right)$ \\
Ortopedi & 5 & 2 & \\
Mata & 2 & 4 & \\
Onkologi & 3 & 4 & \\
Obgyn & 2 & 4 & \\
Digestif & 1 & 0 & \\
THT & 3 & & \\
ASA, n & & 9 & \\
I & 9 & 7 & \\
II & 7 & & \\
\hline
\end{tabular}

Keterangan: *uji chi-kuadrat, **uji T- Independent, ***Uji Mann-Whitney 
Tabel 2 Perbedaan Nilai Neutrofil pada Kelompok A

\begin{tabular}{|c|c|c|}
\hline Waktu & $\begin{array}{c}\text { Neutrofil, } \\
\text { Rata-rata } \\
\text { (SB), \% }\end{array}$ & $\mathbf{p}^{*}$ \\
\hline Sebelum induksi (T1) & $63,17(10,86)$ & 0,643 \\
\hline $\begin{array}{l}10 \text { menit setelah } \\
\text { induksi (T2) }\end{array}$ & $62,64(11,03)$ & \\
\hline $\begin{array}{l}60 \text { menit setelah } \\
\text { insisi (T3) }\end{array}$ & $63,47(11,57)$ & \\
\hline
\end{tabular}

Keterangan: " $\mathrm{uji}$ repeated ANOVA

tidak terdapat perbedaan bermakna $(p>0,05$; Tabel 2).

Nilai neutrofil rata-rata pada kelompok B menunjukkan penurunan dari pengamatan sebelum induksi, 10 menit setelah induksi, dan 60 menit setelah insisi dengan perbedaan yang signifikan $(p=0,032)$. Neutrofil rata-rata sebelum induksi anestesi adalah 65,04\%, kemudian berkurang menjadi $61,83 \%$ pada 10 menit setelah induksi dan turun menjadi $59,97 \%$ pada 60 menit setelah insisi (Tabel 3).

Nilai neutrofil rata-rata sebelum induksi anestesi pada kelompok A adalah 63,17\% dengan simpangan baku 10,86\%, sedangkan pada kelompok B adalah 65,04\% dengan simpangan baku 11,35\%. Analisis statistika menggunakan uji T-independent menunjukkan tidak terdapat perbedaan nilai neutrofil ratarata yang signifikan sebelum induksi antara kelompok A dan $B(p=0,636)$. Pada pengamatan 10 menit setelah induksi dan 10 menit setelah insisi juga tidak terdapat perbedaan nilai neutrofil rata-rata yang signifikan antara dua kelompok studi ( $p>0,05$; Tabel 4).

Meskipun berdasar atas analisis statistik tidak ditemukan perbedaan rata-rata yang
Tabel 3 Perbedaan Nilai Neutrofil pada Kelompok B

\begin{tabular}{lcc}
\hline \multicolumn{1}{c}{ Waktu } & $\begin{array}{c}\text { Neutrofil, } \\
\text { Rata-rata } \\
\text { (SB), \% }\end{array}$ & $\mathbf{p}^{*}$ \\
\hline Sebelum Induksi & $65,04(11,35)$ & 0,032 \\
$\begin{array}{l}\text { 10 menit setelah } \\
\text { induksi }\end{array}$ & $61,83(12,35)$ & \\
$\begin{array}{l}\text { 60 menit setelah } \\
\text { insisi }\end{array}$ & $59,97(11,76)$ & \\
\hline
\end{tabular}

Keterangan: " ${ }^{u j i}$ repeated ANOVA

signifikan, namun pada kelompok B nilai neutrofil lebih rendah daripada kelompok A. Nilai neutrofil rata-rata 10 menit pascainduksi pada kelompok B adalah 61,83\% sedangkan pada kelompok A dengan rata-rata 62,64\%. Begitupun hasil pengamatan pada 60 menit pascainsisi, neutrofil rata-rata pada kelompok B lebih rendah daripada kelompok A $(59,97 \%$ vs 63,47\%; Gambar).

\section{Pembahasan}

Data demografi sampel terhadap jenis kelamin, usia, berat badan rata-rata, dan status fisik ASA tidak terdapat perbedaan yang signifikan antara kedua kelompok perlakuan $(\mathrm{p}>0,05)$. Simpulan analisis karakteristik antara kedua kelompok perlakuan bahwa kedua kelompok perlakuan adalah homogen.

Nilai neutrofil rata-rata sebelum induksi, 10 menit setelah induksi (T2), dan 60 menit setelah insisi (T3) secara statistika tidak terdapat penurunan neutrofil yang signifikan pada pemberian induksi dengan propofol $(p>0,05)$. Pada penelitian sebelumnya oleh Corcoran dkk. ${ }^{7}$ dan Schilling, dkk. ${ }^{8}$ dilakukan

Tabel 4 Perbedaan Nilai Neutrofil antara Kelompok A dan B

\begin{tabular}{lccc}
\hline \multicolumn{1}{c}{ Neutrofil Rata-rata (SB), $\boldsymbol{\mu} \%$} & Kelompok A & Kelompok B & Nilai $^{*}$ *) \\
\hline Preinduksi & $63,17(10,86)$ & $65,04(11,35)$ & 0,636 \\
10 menit posinduksi & $62,64(11,03)$ & $61,83(12,35)$ & 0,846 \\
60 menit posinsisi & $63,47(11,57)$ & $59,97(11,76)$ & 0,403 \\
\hline
\end{tabular}

Keterangan: *Uji T-independent 


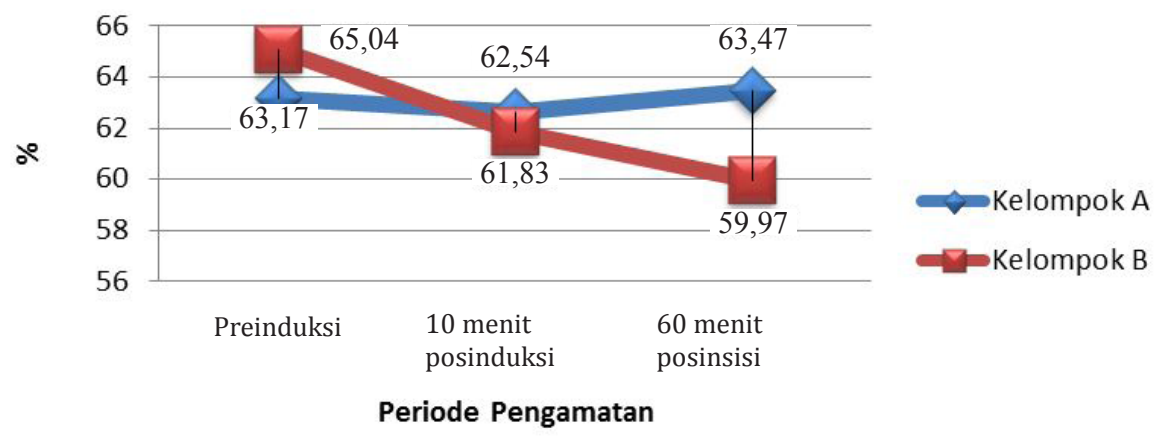

Gambar Grafik Garis Perbedaan Neutrofil Rata-rata antara Kelompok A dan B

dengan memberikan perlakuan infus kontinu terhadap pasien untuk melihat fungsi neutrofil. Penelitian lain dilakukan oleh FuHai dkk. ${ }^{9}$ secara in vitro untuk melihat fungsi neutrofil. Pada penelitian ini propofol hanya diberikan pada awal menjelang operasi dan hanya sebagai induksi dan tidak diberikan infus kontinu sebagai pemeliharaan anestesi sehingga tidak dapat melihat efek propofol yang lebih lama pada pasien.

Nilai neutrofil rata-rata pada T1, T2, dan T3 didapatkan penurunan nilai neutrofil yang signifikan pada pemberian induksi dengan ketamin $(p<0,05)$. Penelitian sebelumnya oleh Lewis dkk. ${ }^{10}$ dilakukan dengan memberikan perlakuan ketamin dosis besar secara in vitro. Pada penelitian lainnya yang dilakukan Broun, dkk. ${ }^{11}$ dilakukan secara in vitro untuk melihat fungsi neutrofil. ${ }^{11}$ Pada penelitian ini ketamin hanya diberikan pada awal menjelang operasi dan hanya sebagai induksi dan tidak diberikan infus kontinu sebagai pemeliharaan anestesi sehingga tidak dapat melihat efek ketamin yang lebih lama pada pasien yang mungkin dapat berpengaruh secara signifikan secara klinis terhadap perubahan nilai neutrofil dan leukosit.

\section{Simpulan}

Pada penelitian ini dapat disimpulkan bahwa terdapat penurunan neutrofil pada pemberian induksi ketamin dibanding dengan pemberian propofol. Penurunan neutrofil pada induksi ketamin mungkin memiliki efek yang lebih baik bila digunakan pada pasien infeksi atau sepsis yang nilai neutrofil telah meningkat di atas batas normal sebelum tindakan anestesi.

\section{Daftar Pustaka}

1. Beilin B, Rusabrov Y, Shapira Y, Royblat L, Greemberg L, Yardeni IZ, dkk. Low-dose ketamine affect immune responsses in humans during the early postoperative period. Br J Anaesth. 2007;99(4):522-7.

2. Shin K, Masato K. Anesthetics, immune cells and immune responsse. J Anaesth. 2008;8(1):1-19.

3. Fold JD. Overview of immunity. Dalam: O'Gorman MRG, Bonnenberg AD, penyunting. Edisi ke-2. Handbook of human immunology. New York: CRC Press/ Taylor \& Francis Group; 2008. hlm. 1-28.

4. Erbas M, Toman H, Gencer M, Sahin H, Hiras HA, Simsik T. The effect of general and spinal anesthesia on neutrophil to lymphocyte ratio in patient undergoing cesarian section. Anaesth Pain Intens Care. 2015;19(4):485-8.

5. Kim C, Sakamoto A. Differences in the leukocyte responsse to incision during upper abdominal surgery with epidural versus general anesthesia. J Nippon Med Sci. 2006;73(1):4-9.

6. Roesslein M, Schibilsky D, Muller L, Goebel U, Schwer C, Humar M, dkk. Thiopental protects human $t$ lymphocytes from apoptosis in vitro via the expression of heat shock protein. J Pharmacol Exp Ther. 2007;325(1):217-25.

7. Corcoran TB, Engel A, Sakamoto H, O'Shea 
A, O'Callaghan-Enright S, Shorten GD. The effect of propofol on neutrophil function, lipid peroxidation and inflammatory responsse during elective coronary bypass grafting in patients with impaired ventricular function. $\mathrm{Br} \mathrm{J}$ Anaesth. 2006;97(6):825-31.

8. Schilling T, Kozian A, Kretzchmar M, Huth C, Welte T, Buhling F, dkk. Effects of propofol and desflurane anaesthesia on the alveolar inflammatory responsse to one-lung ventilation. Br J Anaesth. 2007;99(3):36875.

9. Fu-Hai J, Yu-lan W, Jian-Ping Y. Effect of propofol anesthesia and sevoflurane anesthesia on the differentiation of human t-helper cells during surgery. Chinese Med J. 2011;124(4):525-9.

10. Lewis E, Rogachev B, Shaked G, Douvdevani A. The in vitro effects of ketamine at large concentration can be attributed to a nonspecific cytostatic effect. Anesth Analg. 2010;92:927-9.

11. Broun S, Gaza N, Werdehausen R, Hermanns H, Bauer I, Duriex ME, dkk. Ketamine induces apoptosis via the nitochondrial pathway in human lymphocytes and neuronal cells. $\mathrm{Br} \mathrm{J}$ Anaesth. 2010;105(3):347-54. 